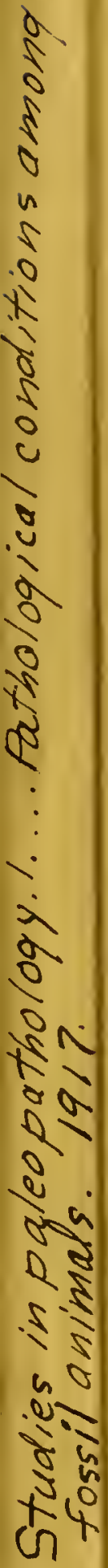

$+1+=$

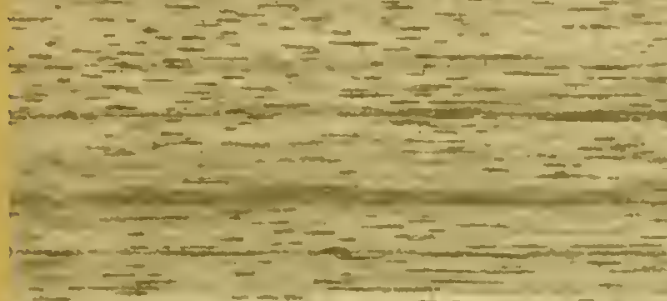

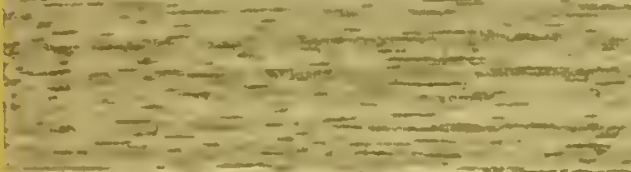

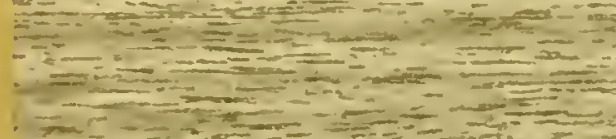

and

and

-

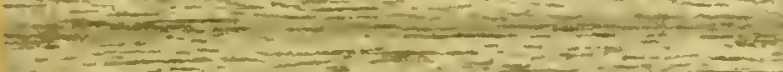

and

a

$\frac{0}{8}$
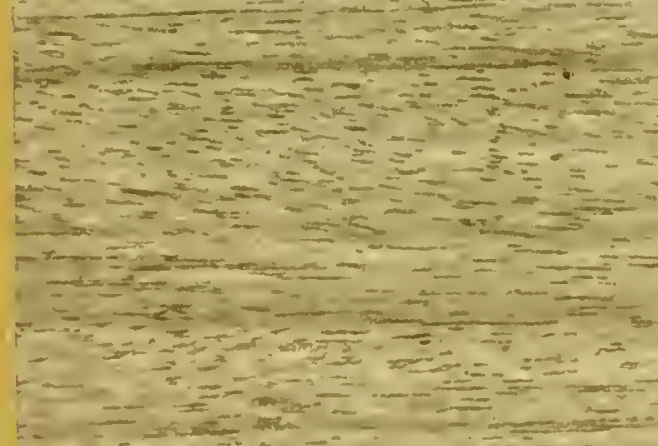


\section{HARVARD UNIVERSITY}

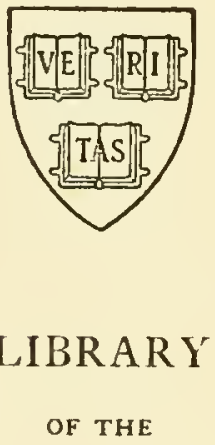

Museum of Comparative Zoölogy 



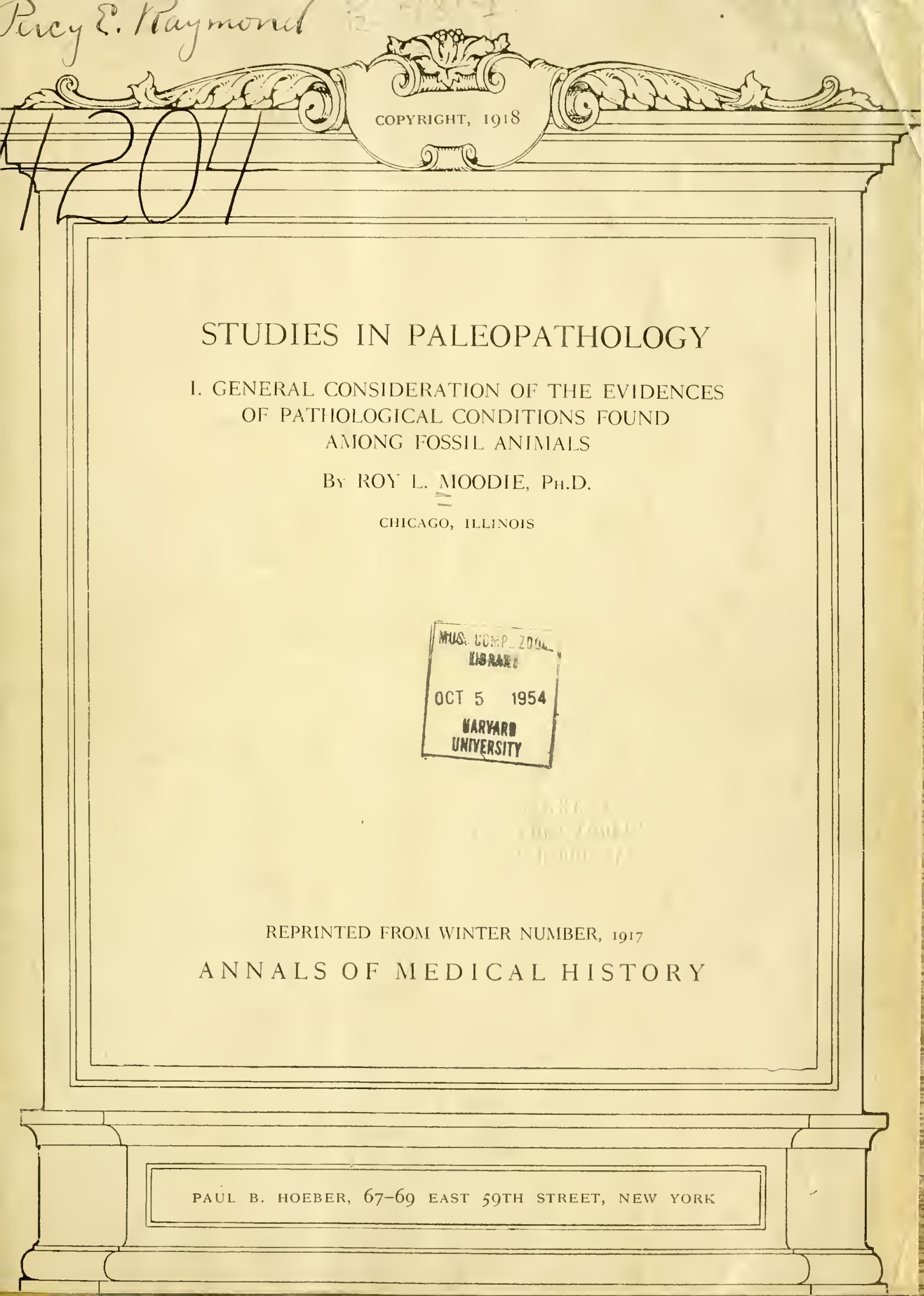




\title{
STUDIES IN PALEOPATHOLOGY
}

\author{
I. GENERAL CONSIDERATION OF THE EVIDENCES OF \\ PATHOLOGICAL CONDITIONS FOUND AMONG FOSSIL ANIMALS \\ By ROY L. MOODIE, PH.D. \\ Department of Anatomy, College of Medicine, University of IIlinois \\ CHICAGO, ILLINOIS
}

\section{DEFINITION AND SCOPE OF PALEOPATHOLOGY}

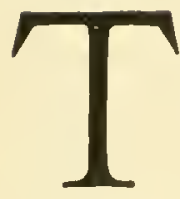

HE study of the evidences of disease among ancient man and fossil animals is known as paleopathology, the term having first been applied by Sir Narc Armand Ruffer in $1914^{2}$ to methods he had developed in studying the pathological anatomy of the ancient Egyptian nummies. He defined it as follows:

"Paleopathology is the science of the diseases which can be demonstrated in human and animal remains of ancient times."

The significance of the term has been dwelt upon by Kkebs, ${ }^{3}$ and a further extension of its meaning to include, not only the diseases of the ancient Egyptians but those of prehistoric man and fossil animals as well, has been suggested by the writer. ${ }^{4}$ The field thus involved includes the resources of anthropology and paleontology, as well as some details contained in archeological studies.

${ }^{1}$ Sir Mare Armand Ruffer, distinguished for his work in preventive medicine and for his studies on the pathology of the Egyptian mummies, lost his life while engaged in Red Cross work. See: "Memorial Notice of Sir Marc Armand Ruffer," by F. H. Garrison, Ann. Med. History, 1917, vol. i, No. 2, pp. 218-220, with portrait.

${ }^{2}$ Ruffer: "Studies in Palæopathology in Egypt," J. Paib. Bacteriol. 1914 , vol. I8, p. 149.

${ }^{3}$ Klcbs: Jobns Hopkins Hosp. Bull. 1917, vol. 28, pp. $261-266$.

4loodie: Am.J.Sc. 1916, vol. 41, pp. 530-531; Science, N. S. 1016, vol. xliii, p. 425 .

${ }^{5}$ The term prebistoric, of course, usually refers to events prior to the details of recorded human history, and is variously designated according to
The present paper deals mainly with the so-called prehistoric, ${ }^{5}$ and especially prehuman, evidences of disease (prior to 500,000 в.C.) of the extinct vertebrates. It is interesting to note that the history of disease, from the frrst geological evidences at present obtainable down to the historical data contained in August Hirsch's "Handbook of Geographical and Historical Pathology" (circa 600 B.C. to 1875 A.D.), will be seen as a series of consecutive events from the introduction of diseased conditions among animals and plants down to the present time. There can be no doubt that many of the diseases existing today are of very great antiquity, having a history extending back into geological time for many millions of years.

It is not necessary nor pertinent to review in this place the studies of Ruffer, Elliot Smith, Wood Jones, Rietti, Fouquet and other' writers on the pathological anatomy of the ancient Egyptian nummies, since their results are so readily accessible. Their

the region under discussion. Thus in Egypt any grave earlier than the time of the first dynasty is often called prehistoric. This implies an age of 6,000 years or more. In France LeBaron defines the prehistoric period as closing at about 22.2 B.C., and several centuries later in Algeria. To the paleontologist the term is meaningless. Klebs has said: "The adjective 'prehistoric,' used so often, would seem a misnomer, because the distinction of a history read in written records from one seen and studied in equally characteristic objects, clironologically determinable, is purely arbitrary and artificial and it would do no harm to drop it altogether." 
material might be regarded, from a certain standpoint, as fossil, meaning something "dug up." The term fossil, however, as used in this paper refers to material which is thoroughly petrified, the age of which must be reckoned by geological standards. The studies of the above-mentioned writers have been briefly reviewed and summarized by Garrison, ${ }^{6}$ Klebs, ${ }^{7}$ and Sudhoff, ${ }^{8}$ and will be extensively referred to elsewhere by the writer.

The studies of Ales Hrdlicka and Langdon $^{9}$ on the pathological anatomy of the North American Indians, and of Hrdlička, Eaton $^{10}$ and other writers on the ancient Peruvians, must also be neglected, as well as the meager details of fossil man as they are recounted in the various works on anthropology. The subject of the diseases of ancient human races has never been systematically studied. The writer will present a consideration of this subject at some future time.

\section{PALEONTOLOGICAL EVIDENCES OF DISEASE}

The study of paleopathology is still in its initial stages, and especially is the application of pathological methods to fossil lesions a new field. But the comparative scantiness of facts so far brought out and the difficulties of research should not hinder its successful prosecution. What the final results may be remains to be seen. The immediate results are certain to bring attention to the presence of characteristic lesions of disease far back in geological time, and it is very interesting, if not important, to find in past geological ages evidences of

${ }^{6}$ Garrison: "History of Medicine," 1917, 2nd ed., p. 50; Ann. Med. History, I917, vol. I, No. 2, p. 219 .

'Klebs: Johns Hopkins Hosp. Bull. 1917, vol. 28, pp. $261-266$.

"Sudhoff: J. L. Pagel's "Einführung in die Geschichte der Medizin," p. 33.

9 Langdon: "The Madisonville Prehistoric Cemetery. Anthropological Notes," J.Cincin. Soc. Nat. Hist. I88o, vol. iii, p. 40; I881, vol. iv, p. 250 , pathological processes which are so familiar to us today. If we can trace the known lesions to any definite cause among the crtinct animals it will be a step toward the erection of the newest branch of pathology, dealing with the oldest aspects of that science.

In regard to the importance of this branch of study, Klebs ${ }^{11}$ says:

"We nced only consider what definite influence diseases exert in our individual lives, what profound social upheavals were brought about through the incidence of epidemics, less perceptibly perhaps but none the less strongly, through widespread chronic ailments, through professional diseases, how whole districts and countries are forsaken because discase made them uninhabitable, how disease affecting early childhood and others producing sterility led to the gradual extinction of whole peoples. . . . For the grasp of such problems, the study of discase as it appears to us now does not suffice; the traces left during immense periods of time have to be taken into account and it is in just such questions, not approachable by other methods, that paleopathology in time to come may furnish important solutions."

The attitude of students of paleontology toward this subject has been negative. Even men like Leidy, a trained anatomist and an eminent medical man, paid scant attention to the subject, although he did describe an example of caries in a mastodon tooth ${ }^{12}$ from Florida. Cuvier too, eminent as he was in the field of comparative anatomy, failed to recognize the importance of this phase

Figs. I-22. Good discussion of pathology of early North American Indians.

${ }^{10}$ Eaton: "The Collection of Osteological Material from Machu Picchu," Mem. Connect. Acad. Arts Sc. May, 1916, vol. v.

"Klebs: Jobns Hopkins Hosp. Bull., 1917, vol. 28, pp. $26 \mathrm{I}-266$.

12 Leidy: Proc. Acad. Nat. Sc., Philadelphia, I886, p. 38 . 
of paleontology. His discussions of the few lesions he recognized were meager and inadequate. He has described a fractured skull of a Pleistocene Hyxna and a fractured femur of Anoplotherium.

Paleontology lends considerable light to the study of the antiquity of disease. The study of the lesions so far known among fossil animals indicates nothing new in the nature of pathological processes but simply extends our knowledge of disease to a vastly earlier period than had previously been known. It seems quite probable that some of the diseases exhibited by the extinct vertebrates went out of existence with the race of animals which were afflicted. If this proves to be true it will be an interesting opportunity to study the details of lesions of extinct diseases. There seems to be little possibility of determining the fundamental cause of disease other than is already known; for disease is apparently one of the manifestations of life, and has followed the same lines of erolution as have plants and animals, and is possibly directed by the same factors. Such a study as the present may, however, throw light on the origin of many of the diseases to which the human race is a prey. A knowledge of the pathological processes which have taken place in animals of geological antiquity will aid in an understanding of the general nature of disease.

The literature of vertebrate paleontology contains a number of incidental references to the diseased nature of the fossilized bones of fishes, reptiles, birds, and mammals, the lesions described indicating a variety of diseases, some of which are not uncommon today. It is manifestly impossible to diagnose correctly, on the basis of our modern

${ }^{13}$ Among diseases which have become extinct within historical times may be mentioned the sweating sickness described by Hecker in "Epidemics of the Middle Ages," 1846, pp. 181-353.

14 The soft parts of fossil vertebrates have been discussed by a number of writers. Our knowledge of the entire subject is reviewed in the author's paper, "A New Fish Brain from the Carboniferous knowledge of recent diseases, all of the lesions which are preserved in a fossil sondition. In the extinction of the ancient races of animals, certain diseases, without doubt, became extinct with them, ${ }^{13}$ and it is partly the purpose of this paper to inaugurate an inquiry into the nature of the diseases of fossil vertebrates. No one has yet made a study of the evidences of disease among fossil animals, since these conditions, whenever noted, have been referred to only in an incidental way, by writers on paleontological subjects.

Geological evidences of the diseased state of animals are necessarily restricted to pathological lesions on the hard parts of fossil animal remains. Soft parts ${ }^{14}$ are seldiom fossilized, and the few specimens known have not been subject to disease. Since the pathological changes which affect the hard parts of animals today are relatively few when compared to the diseases which aillict the body as a whole, it is to be supposed that the paleontological evidences of disease are but partial indications of the prevalence of pathological conditions in geological time. The following account, too, must be read in the light of the paucity of evidence available for discussion. The details are meager, but since they are all we have, they may be deemed worthy of consideration.

It will be clearly evident, after a consideration of geological matters, that all paleontological evidence is of relative value, since such small portions of the ancient faunas and flora are preserved in the rocks. However, we are safe in stating, from such evidence as we have, the probabilities of the occurrence of numerous diseases among extinct animals, just as it is safe for us to state, on the basis of a single tooth in a of Kansas, with a Review of Other Fossil Brains," J. Comp. Neurol., April, 19I5, vol. 25, No. 2, where an annotated bibliography of fifty papers will enable the interested reader to see just how meager is our knowledge of the soft parts of extinct vertebrates. Many of the softer structures are represented by impressions on the stone. 
definite geological horizon, that such and such an animal existed at the time the formation was being deposited, provided, of course, the deposit is a primary one and the fossil was not moved by shifting in a secondary deposition.

All that we know of the earliest land vertebrates, prior to the Pennsylvanian, for instance, is a single footprint from the Devonian, and a few series of footprints from the Mississippian. On the basis of these footprints we are able to say definitely that there existed in North America a diversified fauna of vertebrates, probably amphibian, which preceded the well-known amphibian faunas of the great Coal Period.

\section{DEFINITION OF DISEASE AS USED IN THIS STUDY}

Disease, as the term is used in this study, may be defined as any deviation from the healthy or normal state of the body which has left a visible impress upon the fossilized skeleton. The evidence may take the form of broken bones, tumors, necroses, hyperplasias and arthritides of various kinds. Only the diseases of animals have been considered. This is done with a full realization of the enormous domain of phytopathology and is a confession of a limitation to a restricted field. Some of the paleobotanical literature has been read, but apparently no attempt has been made to trace the rise and progress of phytopathology from fossil material.

This is doubtless due to the unsatisfactory condition of fossil plant material which is usually quite fragmentary. Some idea of the nature of plant diseases of the past may be had from the following brief summary ${ }^{15}$ for which 1 am indebted to Professor Edward II. Berry:

"Bacterial and fungus activity are known in Carboniferous plants, and would

15 Berry: Letter to author, Jan. 4, 1918.

${ }^{16}$ Berry: "Remarkable Fossil Fungi," Mycologia, probably be detectable at much earlier horizons if petrified material of greater age were avaliable for study, since the bacteria appear to be among the earliest forms of life. Material preserved as impressions at all horizons, more especially the post-Paleozoic ones, show abundant leaf-spot fungi, and such remains from the Cretaceous and Tertiary show abundant insect galls and leaf cutting by caterpillars or bees; but this class of material is usually more or less indefinite. Whenever one handles much petrified material, one is struck with traces of fungal ravages and bacterial action."

EVIDENCES OF DISEASE IN FOSSIL PLANTS

It is often diffrcult to decide whether the ravages of fungi and bacteria are pre- or post-mortem. The agents of decay are well known to have existed carly in geological time. During the Carboniferous there existed conditions which were especially favorable to the growth of a mycological flora, and much of it was probably on dead plant material.

Professor Berry writes further ${ }^{16}$ concerning the primitive fungi:

"Among the relics of former vegetation that carry the record back many millions of years the remains of fungi are so rarely found that their presence is always exceptional, although it is obvious that many times during the long history of the earth the environment has offered optimum conditions for their abundant development. To mention but one such occasion, that of the formation of the Coal Measures must have witnessed an exceedingly abundant mycological flora. That these plants were present thus early is indicated by the abundance of hyphæ, and other traces of fungal activity such as butyric fermentation, in the tissues of I9i6, vol. 8, No. 2, pp. 73-78, plates i80-182, containing 16 figures. 
Carboniferous vascular plants, and the scarcity of described forms must be attributed to the perishable nature of most fungal tissues and to the lack of systematic work by experienced mycologists on the more or less obscure material available. To be sure, quite a considerable number of fossil forms referred to Fungi have been recorded from various geologic horizons but the vast majority of these are leaf-spot types based upon real or fancied resemblances, and found on impressions of foliage and without definite botanical characters. Some doubtless represent fungal ravages, others are due to insects, some are glandular, and others are purely imaginary."

Professor Berry refers to A. Meschinelli's "Fungorum Fossilium Omnium lconographia," (1902, I 44 pp., 31 plates), for a rather complete illustrated list of all of the forms referred to down to the year 1900. Other and more complete studies on the bacteria and fungi of the Coal Measures of France particularly have been made by Van Tieghem and Renault. A fairly complete list of their numerous papers is to be found in Smith's bibliography. ${ }^{17}$ Other information may be gleaned from the memoirs and textbooks dealing with Paleobotany.

${ }^{17}$ Erwin F. Snith: "Bacteria in Prehistoric Times." In "Bacteria in Relation to Plant Diseases," 1905, vol. 1, p. 262.

${ }^{18}$ The question of extinction is still one of the unsolved problems of paleontology. The importance of those discases which leave an impress on the skeleton has been referred to by the author in the following words:

"It is not my intention to contend that disease has not been influential in the extinction of races (or species); it probably has been; but those diseases which have left an impress on the fossilized skeleton certainly cannot be regarded as among those diseases which would produce widespread extinction. Some other lias been the dominant factor. The present results of the study of fossil pathology indicate the early appearance in geological time and widespread distribution of discases of many

\section{METCHNIKOFF ON DISEASES IN REMOTE EPOCHS}

The possible presence of disease among animals of remote epochs of the earth's history was suggested by Élie Metchnikoff in the following words:

"Diseases in general and infective diseases in particular were developed on the earth at a very remote epoch. Far from being peculiar to man, animals and the higher plants, they attack inferior forms and are widely distributed among. unicellular organism, Infusoria and Algæ. Diseases undoubtedly play an important rôle in the history of life on our planet, and it is very probable that they have contributed in a marked degree to the extinction of certain species. ${ }^{18}$ When we observe the ravages produced by parasitic Fungi among the young fish which we are trying to rear, or the destruction of cray-fish in certain countries in consequence of the rapid increase of epizoötic germs, we are involuntarily led to the conclusion that pathogenic micro-organisms must have brought about the disappearance of certain animal and vegetable species." 19

It would be interesting in this connection to know Metchnikoff's sources of information relative to the presence of diseases at remote epochs. Virchow's studies on the

kinds, but none of them, so far as the fossil lesions may be interpreted, were sufficiently severe to have played a part in the extinction of any of the known groups of fossil vertebrates. They are to be regarded rather as chronic infectious or constitutional diseases which may have played a part in extinction, but there must have been some other and more powerful ally which is at present unknown." ("The Influence of Discase in the Extinction of Races," Science, N. S., Jan. 19, 1917, vol. xlv., No. I 151, pp. 63-64.

${ }^{19}$ Élie Metchnikoff: "Immunity in Infective Diseases," 1915. Translated from the French by Francis G. Binnie, p. 8. 
cave bears of Europe ${ }^{20}$ were well known, and his characterization of the arthritic lesions of the fossorial anmals as the "Höhlengicht," was certainly famous at the time Metchnikoff wrote. The studies of Mayer $^{21}$ on the lesions of the cave bears and care lions of Europe as well as the writings of Cuvier (1820), Esper (1774), (oldfuss (I8Io), Walther (182j), Schmerling (183j), Owen (18+2), Schaafhausen (18;8), Newton and Parker (1870), Graff ( $188 ;$ ) and Leidy (I886) may, any or all of them, have been known to Metchnihofl. They all suggest the pathology of ancient times and some deal entirely with the pathological anatony of fossil remains. None, however, are studies which deal with remains older than the middle Tertiary, and to a paleontologist the term "remote epoch" Irardly applies, when compared to lesions known from the Carboniferous, for example. I am, therefore, forced to conclude that Metchnikoff simply forecasted what would be discovered, on the basis of what he knew in modern plants and animals. All of the literature in paleontology dealing with pathological evidences of any great antiquity, prior to the mid-Tertiary, has appeared since 1900 . The literature is meager and unsatisfactory. Paleontological studies seldom deal specifically with diseased conditions, so that the field is still to be explored. The studies in paleontology dealing with pathological evidences among fossil vertebrates have been reviewed by

${ }^{20}$ Rudolf Virchow: "Ueber einen Besuch der west-fällischen Knochenhöhle," Ztschr. I. Ethnol. 18-o, Bd. 2, p. 36\%, footnote; "Knochen vom Höhlenbären mit krankhaften Veränderungen," Ibid., 1895, Bd. 27, pp. 706-708, figs. I-4: “Beitrag zur Geschichte der Lues," Dermat. Ztscbr., I 896, Bd. 3, p. 4 .

${ }^{21}$ Mayer: "Ueber krankhafte Knochen vorweltlicher Thiere. In "Nova Acta Leopoldina (Novorum Actorum Academia Cæsareæ Leopoldino-Carolinæ Naturæ Curiosum)", Bd. xxiv', pt. 11, pp. 6-3-689. pl. 30.

${ }^{22}$ O. Abel: "Grundzüge der Paleobiologie der
Abel, ${ }^{22}$ and a much fuller review is planned for a memoir on paleopatholory. now in preparation.

\section{APPARENT ABSENCE OF DISEASE AMONG}

EAIRLY PALEOZOIC ANIMALS

A careful study of the literature of paleontology shows that, so far as present observations are concerned, the animals of the eartier periods of the earth's history were free from disease. Although bacteria ${ }^{23}$ are known to have occurred in the algal deposits of the Newland limestone, a formation of the Beltian series of Algonkian rocks in central Montana, they are not known to have been of a pathogenic nature, but rather are supposed to have been active in the deposition of limestones, together with the alga with which they were associated. No lesions due to accident or to infection have been described among either the vertebrates or invertebrates of the early geological periods, prior to the Carboniferous. This lack of knowledge concerning the evidence of disease may be due to ignorance on our part, for the lesions may have been seen but were not deemed worthy of description. Or, it may be due to the fact that the invertebrates of the Proterozoic and Paleozoic, which were the predominant types of animal life during these periods, were free from disease which affected the skeleton, as are, in general, the invertebrates of today, although many of the

Wirbelthiere," 1912; "S,uren von Kämpfen," pp. 88-91; "Kinochenerkrankungen," pp. 9I-95.

23 These bacteria are described and figured by C. D. Walcott and H. F. Osborn.

C. D. Walcott: "Discovery of Algonkian Bacteria," Proc. Nal. Acad. Sc., April 1015, p. 256 ; "Evidences of Primitive Life," Smilbsonian Rep. for 1915, pp. 235-255, illustrated.

H. F. Osborn: "Origin and Evolution of Life," 1917, p. 153: Science, N. S., I917, vol. 46, No. I I92, PP. $432-434$.

Their discovery was forecasted by $\mathrm{Walcott}$ in his "Pre-Cambrian Algal Flora," Smitbsonian Misc. Collect, I914, vol. 64, No. 2, p. 95. 
recent forms are highly parasitized and are occasionally subject to disease. It appears probable that vertebrates have been more liable to diseases which afflict the hard parts than have the invertebrates, and this liability to pathologic processes has been increased with the passage of geologic time.

\section{IMMUNITY IN MODERN INVERTEBRATES}

The greater immunity of early Paleozoic animals to disease, based on the evidences of paleontological material, is probably not a true index to actual conditions, though it nay be so. It is probably not safe to conclude from present-day conditions what the state of Paleozoic animals may have been as regards disease. At any rate the paleontological evidences are not wholly substantiated by conditions found in modern forms. Metchnikof ${ }^{24}$ has called attention to the occurrence of epidemics of a severe nature among protozoa, such as diseases in Amobx caused by the Microspbrara and the disease in Actinophrys attributed to Fungi allied to the genus Puthium. Pasteur's studies on the pébrine and flacberie of the silkworms will be remembered as instances of severe epidemics in an invertebrate group. Molluscs, however, are apparently largely immune to infection, and since the molluscous animals formed such a large percentage of the preserved faunas of the early periods of the earth's history we may attribute our ignorance of the presence of disease to this factor, in part at least. The immunity of many intermediate hosts to

${ }^{24}$ Metchnikoff: "Immunity in Infective Diseases," translated from the French by Francis G. Binnie, I905, p. I8; also Chap. iii.

${ }^{25}$ Edward Hindle: "Flies in Relation to Disease (Blood sucking Flies)," r9i.4.

G. S. Graham-Smith: "Flies in Relation to Discase (Non-Blood suching Flies)," I9if.

${ }^{26}$ Elias Metchnikoff: "Die Lehre von den Phygocyten und deren experimentellc Grundlagen." In "Kolle und Wassermann's Handbuch der pathogenen Mikroorganismen," I9I3, Bd. ii, erste Hälfte, pp. 655-731, with an excellent bibliography. infection ${ }^{25}$ is well known, and the classical example of the mosquito-borne infections will suffice, although it is well known that insects of many kinds are subject to fatal diseases. Kowalevsky has discussed the anthrax of crickets and many other students have studied the problem. The entire question of immunity in its relation to all forms of extinct animals is of course a new and unsolved, probably an insolvable, problem. But it seems certain that if the early animals were diseased, the ensuing pathology was of such a nature as to leave no impress upon the fossilized part; or else we have not yet learned to recognize these lesions.

\section{THE ORIGIN OF DISEASE}

Phagocy tosis ${ }^{26}$ doubtless began very early in the history of animal life, and it is probable that the natural immunity of the early animals was sufficiently strong to resist the invasion by any pathogenic organisms in sufficient numbers to produce disease. The breaking down of this immunity may possibly be correlated with the development of senescence ${ }^{27}$ among the early races of animals, which reached a climax in some forms - the trilobites, for instance, - at about the time when we find the first indjcations of disease among fossil animals. The breaking down of the immunity, due to the development of race senescence and the introduction of disease, doubtless was of very great importance in the extinction of the trilobites and other great groups

${ }^{27}$ The studies of Charles Emerson Beecher ( 1856 1904), an American paleontologist, upon evolutionary phases of the early fossil brachiopods and trilobites are especially important to consider in connection with the question of race senescence and the extinction of animal groups. His papers have been collected into a volume: "Studies in Evolution," New York, 1901.

The entire subject of senescence in the recent lower animals is discussed by Child in "Senescence and Rejurenescence," University of Chicago Press, 1915. 
of animals which have disappeared from the earth..$^{28}$

I do not intend to assert that senility or senescence is a discase, but that age rreakens the organism and the race and allows the ingress of disease. Minot has stated:

"Old age is not a disease and cannot be cured; it is an accumulation of changes which begin during earliest youth and continue throughout the entire life of the individual."

It may be said that disease in the past has often attacked the races of animals which showed senescence. Many of the virile races of animals in the past were also subject to disease. The paleontological indications of senescence are the reduction in size, the loss of vigor and the production of apparently useless spines as seen in the races of animals which have become reduced or extinct, such as the crinoids, trilobites, brachiopods, anmonites and the dinosaurs. Other examples of senescence may be seen among some of the Permian reptiles which assumed bizarre forms. The tendency of many races of animals to acquire spinous and other useless excrescences of the hard parts shortly before the extinction of the group is noteworthy, and this tendency has been regarded by paleontologists as an indication of senescence.

\section{LESIONS OF PARASITISM IN CAR- BONIFEROUS CRINOIDS}

Our knowledge of the history of disease, as it is based on paleontological evidence, begins with the Carboniferous, when cer-

${ }^{28}$ This suggestion has been discussed by René Larger in his paper "La contre-évolution oú dégénéresence par l'hérédité pathologique cause naturelle de l'extinction des groupes animaux. Essai de paleopathologique générale comparée," 1916, Bull. et mèm. Soc. d'antbrop. de Par.

${ }^{29}$ Graff: "Paleontographica," 1885, Bd. 31, pP. 183-192, Taf. xvi. tain crinoids were afficted in their stems with tumor-like lesions, possibly due to the parasitic action of myzostomids such as commonly attack crinoid stems today. A careful description of the enlarged stems of recent crinoids and the parasitic action of the myzostomids is to be found in the reports of the Challenger Exploring Expedition. A comparison of the ancient and recent lesions on the stems of crinoids leads one to accept the enlargements of fossil crinoid stems as due to the parasitic action of the myzostomids or some similar form.

The evidences for such a conclusion are, apparently, incontrovertible, and have been established by a number of writers on fossil crinoids. Parasitized crinoid stems are known from the Carboniferous of Scotland, Germany (Fig. I) and the Keokuk beds (Fig. 4) of North America. Graff ${ }^{29}$ found the carbonized remains of the parasite in one of the enlargements (Fig. 2) which he studied and which he referred to as the fossilized integument of the myzostomid. The presence of this solt-bodied animal so early in the geological history of the world is not surprising, since from the researches of $\mathrm{Walcott}^{30}$ we know that jellyfishes, sea cucumbers, many types of annulates, and soft-bodied crustaceans lived during the Cambrian, many millions of years earlier. The parasitisn of animals during the Carboniferous was preceded by partial parasitism or commensalism of the earlier periods, and is known to have occurred among fossil corals (Fig. 3) of the Devonian. The intimate association of animals and the origin of parasitism and commensalism during the early part of the Paleozoic has been studied by Clarke. ${ }^{37}$ The reader is referred to his paper for further details.

${ }^{30}$ C. D. Waleott: "Evidences of Primitive Life," Smitbsonian Rep. for 1915 , pp. 235-255, with plates.

${ }^{31}$ John M. Clarke: "The Beginnings of Dependent Life," Fourth Ann. Rep., Director of Science Div., New York State Education Dept., 1908, pp. 1-28. PI. I-13. 
The remains of the early vertebrates prior to the Permian have shown no noteworthy pathological lesions. There may
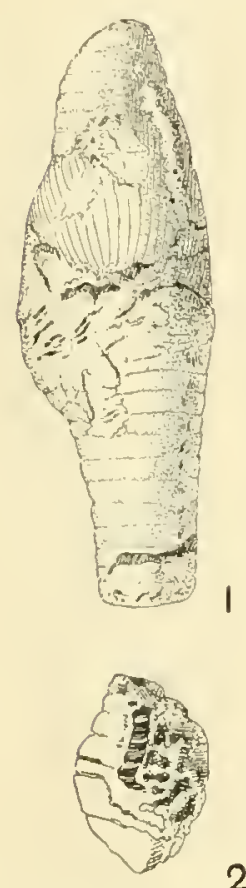

2
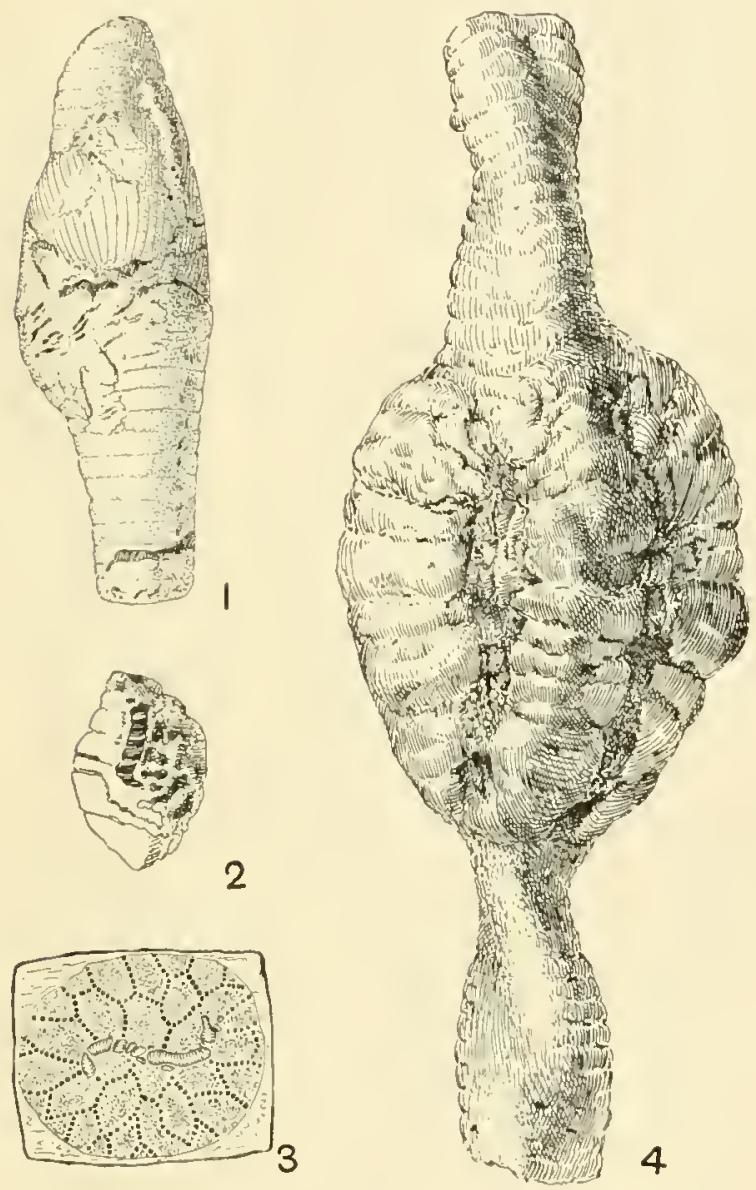

FIG. I. Parasitized stem of a crinoid, from the Carboniferous of Germany, showing the tumorlike mass produced by the action of the niyzostomid. (After Graff.)

FIG. 2. Portion of parasitized erinoid stem, showing carbonized remains of the myzostomid. (After Graff.)

Fig. 3. Section through a fossil coral, Pleurodictyum problematicum from the Lower Devonian of Eifel, showing the worm tube near the center. An example of ancient commensalism. (After Stromer von Reichenbach.)

Fig. 4. An enlarged stem of a crinoid from the Keokuk beds of North America, showing that the enlargement has involved the plates of the stem. This specimen was thoroughly mineralized into a geode, so that no evidences of the parasite were seen. One-half natural size.

have been diseases among these early forms, but the lesions have not yet been discovered. We find, to be sure, certain
Iaterally compressed fishes preserved in the attitude of the opisthotonos and pleurothotonos in horizons prior to the Permian. These attitudes may have been due to spastic distress induced by cerebrospinal infections or to some form of poisoning. Since this subject will be more fully treated elsewhere nothing more need be said than that these attitudes possibly represent diseased conditions of the central nervous system.

\section{PATHOLOGY OF THE PERMIAN VERTEBRATES}

Several pathological conditions are indicated among the vertebrates of the Permian. Renault ${ }^{32}$ has described caries of certain fish bones preserved in coprolites from the Autun basin. He concludes that this type of caries is due to several types of bacteria which he has described and figured. A left radius of Dimetrodon, a primitive reptile, from the Permian of Texas shows an incompletely healed fracture (Fig. 5) with abundant osteosclerosis and some intermediary callus. This is the oldest known case of fracture. It was a simple fracture cutting the bone at right angles, and the healing process has taken place with very little shortening. The bone has no medullary cavity, so that attempts to study the nature of the fracture by means of the $x$-ray have been a failure. The Texas red beds, from which the bone comes, are impregnated with iron, and the radius reacts to the $x$-rays much as a bar of iron would. A fractured rib with an old callus is also known from the Permian of Texas. A description of this lesion with illustrations is to be found in The Surgical Clinics of Cbicago, April, 19i8. Von Huene has described the skull of a phytosaur from the Triassic of Germany, showing a fractured snout with many necrotic sinuses.

${ }^{32}$ B. Renault: "Microorganismes des combustibles fossiles," Bull. Soc. de l'Industrie minérale à SaintEtienne, 1899-1900, Scr. IIl, with atlas of plates. 
DISCUSSION OF GRAPI SHOWING INCREASE OF DISEASE IN GEOLOGICAL TIME

It is not necessary at this timc to go into further details concerning the progress of disease, since the details are to be given in a later paper. The accompanying graph (Fig. 6) will show how, according to present evidences, disease has progressed during the greological history of the earth. The twenty-frve divisions on the base line a-d (Fig. 6) represent as many periods of the earth's history. The divisions on the vertical line $d$-b represent the approximate number of diseases present in each period, as indicated by the known fossil lesions. The time intervals in the graph are shown as of equal value, but the geological periods are not at all of equal duration nor of equal character. This should be kept in mind in studying the graph.

At the point " $a$ " we may say that organic life is first known. It will be seen that the line “ $a-b$,' representing the history of disease, follows a base level for the first twelve periods of the earth's history. Then the

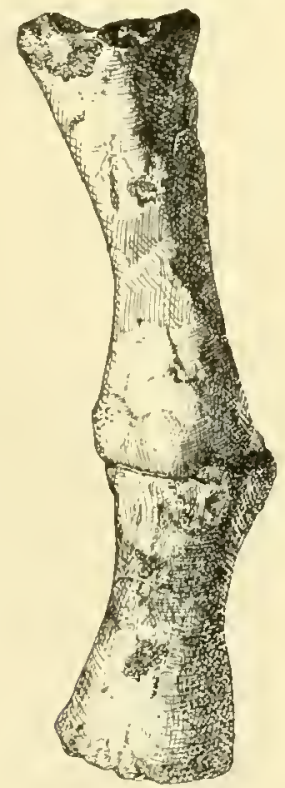

F1G. 5. Callus and fracture in left radius of Dimetrodon, a reptile from the Permian of Texas. The specimen belongs to the Paleontological Collections in Walker Museum, University of Chicago. One-half natural size. curve gradually rises until, during the Cretaceous, at "c," discases and accidentssuch is caries, osteoperiostitis, deforming arthritides, necroses, hyperostosis, oste-

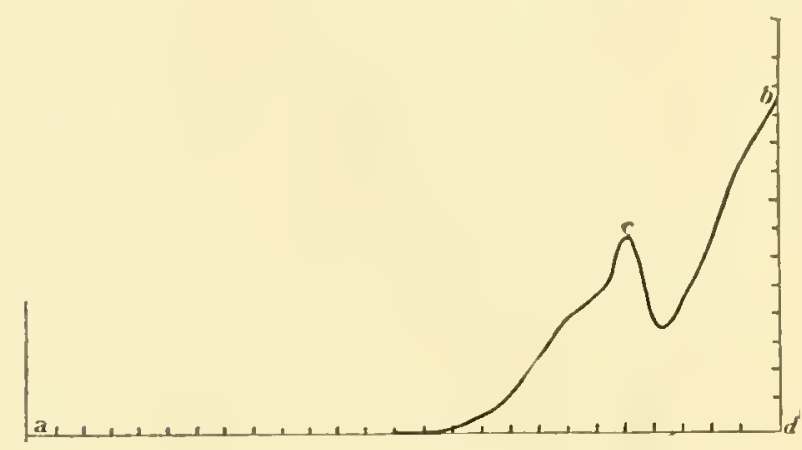

FIG. 6. Graph showing increase of disease in geological time. The $\mathrm{d}$ visions on the base line, $a-d$, represent geo'ogical periods, and on the vertical line prevalence of pathological condit ons.

ophytes, osteomata, fractures-and many infective processes, reached a maximum of development among the dinosaurs, mosasaurs, crocodiles, plesiosaurs, and turtles. The curve suddenly and sharply descends from "c." For with the close of the Cretaceous and the sudden extinction of large groups of the giant reptiles, the incidence of disease also decreased. It seems quite probable that many of the diseases which afflicted the dinosaurs and their associates became extinct with them.

The mammals of the Cretaceous and early Tertiary periods (Fig. 7) do not seem to have been so generally afflicted with disease as were the preceding groups of giant reptiles, nor as were the later mammals. The ascending curve therefore is not so abrupt as one might expect. Certain processes of disease seem to have been acquired by the manmals from preceding forms, for caries and other primitive diseases are evident (Fig. 8) among early Tertiary mammals. The curve rises rapidly, however, and reaches the highest point at "b," indicating that disease is much more prevalent at the present time than ever before in the history of the world. 
The geological development of disease has certain curious characteristics which parallel facts in the evolution of animals and plants. Huxley many years ago called attention geological antiquity a few can certainly be called persistent or primitive types which have remained the same since the close of the Paleozoic. Other diseases arose and

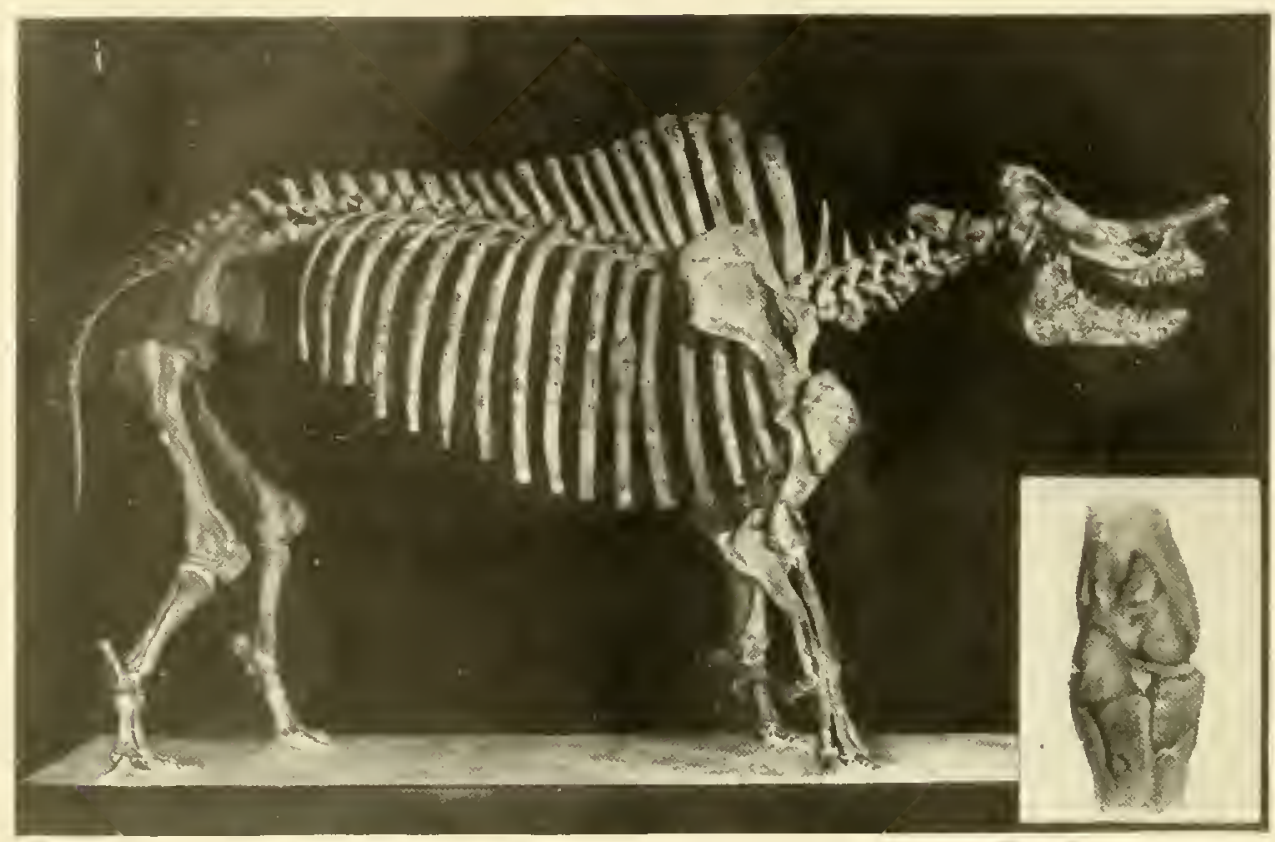

FIG. 7. The skeleton of an early Tertiary mammal, Titanotherium robustum, from the White River Oligocene of South Dakota, as it is mounted in the American Muscum of Natural History. The fifth rib on the right side has been fractured and has healed with a pseudarthrosis and considerable callus. The deta Is are shown in the enlarged sketch in the lower right hand corner. One-sixteenth natural size. (Courtesy of Dr. W. K. Gregory.)

to certain persistent types of animals which had existed almost unchanged from early geological periods down to the present. Among the known diseases (Figs. 9-12) of

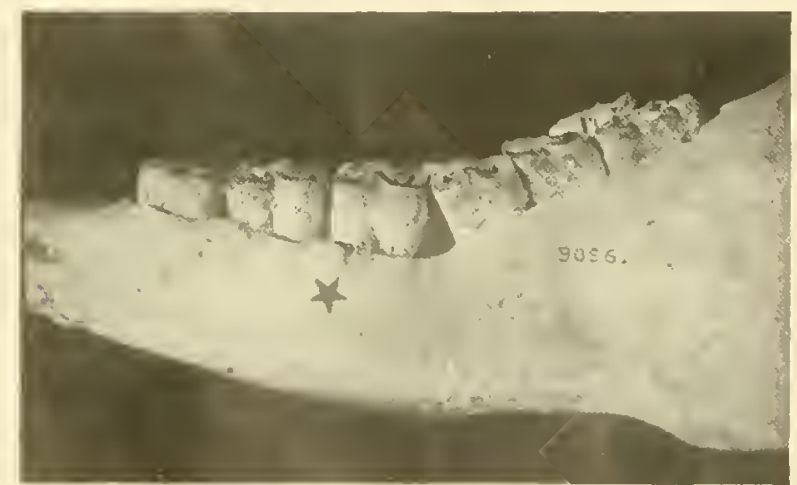

became extinct, but some of them have retained the same characteristics, as seen in the resulting changes of structure.

According to present evidences, disease

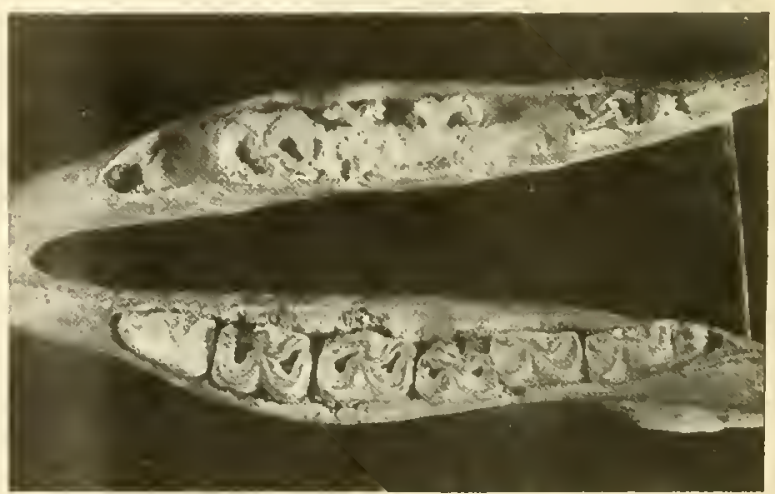

FIG. 8. Two views of the mandible of a three-toed horse, Merycbippus campestris, from the Miocene, about one and one-half million years old. The figures show in the absorbed alveolar margins patho ogical processes simi'ar to alveolar pyorrhea of the present day. A left premolar shows evidences of car es, and the swelling in the left ranius, so evident in the right-hand frgure is indicat've of a fistula, possibly indicating the presence of actinomycosis in the early stages. (Courtesy of Dr. W. D. Mathew) 


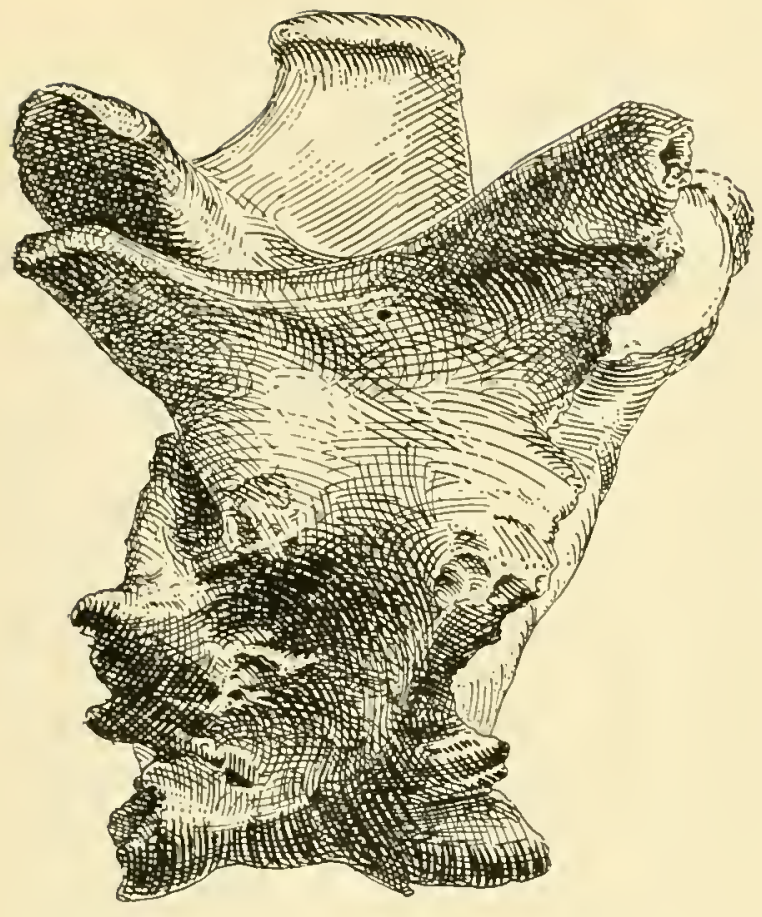

Fig. 9. Lateral view of a dorsal vertebra of a saber-toothed cat, Smilodon, from the Rancho la Brea asphalt beds, Pleistocene, of California, showing the eharacteristic lesions of spondylitis deformans. Natural size. About 500,000 years old.

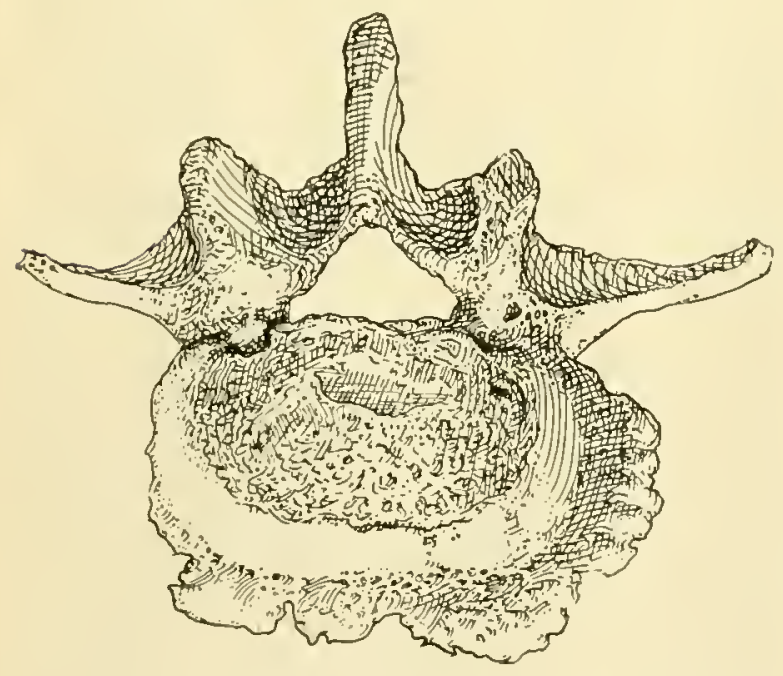

FIG. Ir. Spondylitis in the Iumbar vertebra of an ancient Egyptian. About ;,000 years old. (After Ruffer.)

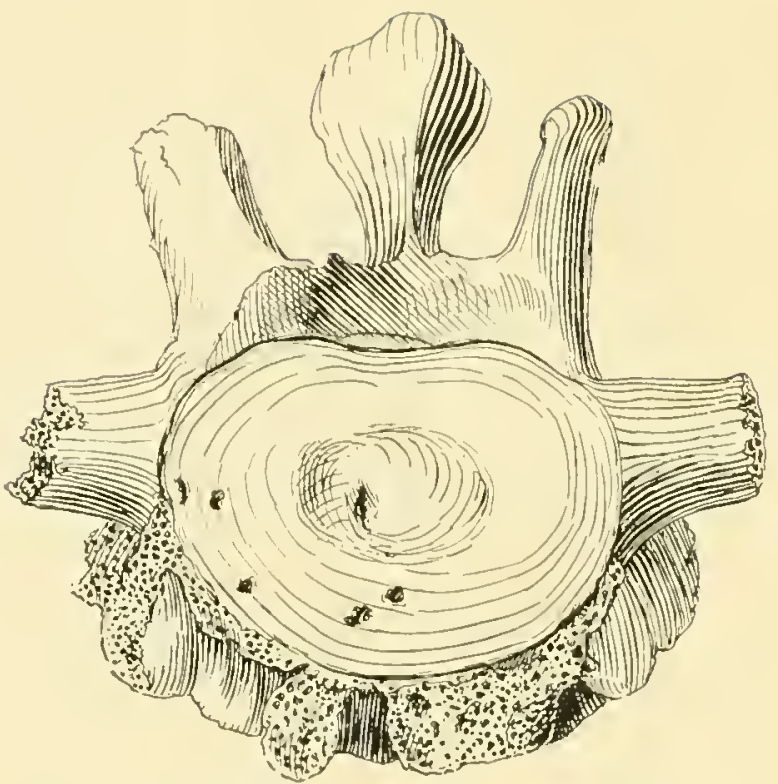

Frg. 10. Posterior view of a dorsal vertebra of a cave bear, Ursus spelæus, from Europe, showing charactcristic lesions of spondylitis deformans. Natural size. About 250,000 years old. (After Mayer.)

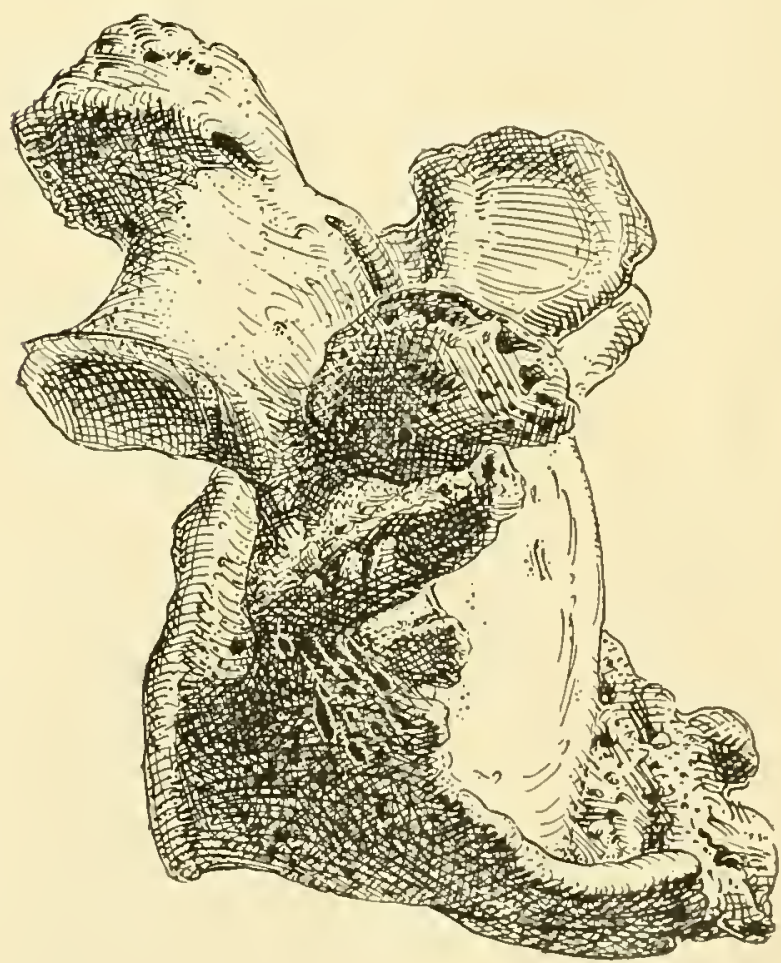

Fig. 12. Spondylitis deformans in a recent human vertebra. NaturaI sizc.

These four figures show the characteristic lesions of this osteoarthritis at different periods of the history of animals and man. So far as external appearances go there has been no change in the pathological processes producing these lesions since the P eistocene at least. Similar lesions of greater antiquity have not yet been seen. 
is, from the geological standpoint, of relatively recent origin and has afflicted the inhabitants of the earth for only the last one-quarter of the earth's history-that is, for the last $25,000,000$ out of a possible

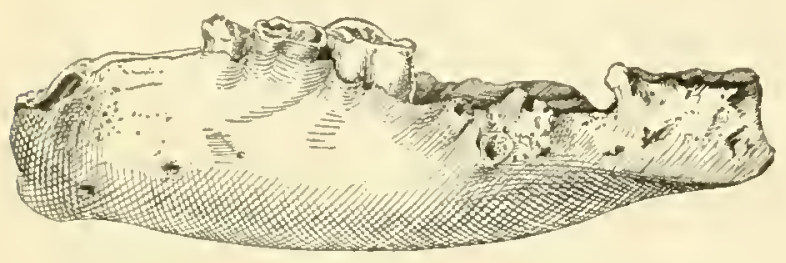

Frg. 13. The mandible of a cave bear, Ursus spe xus, Pleistocene of Europe, showing the ravages of discase. Caries and the absorption of alveolar processes, as well as necrotic sinuses are evident in this mandible. (After Mayer.)

100,000,000 years. Future discoveries will doubtless modify our present conceptions, but the above outline is a summary of our present knowledge of the rise and development of disease among animals.

\section{TABULATION OF GEOLOGICAL EVIDENCES}

The table given below will show at a glance the antiquity of pathological evidences in geological history. The estimates of tine are based upon the relative thickness of the pre-Cambrian and post-Cambrian rocks, after Walcott and Schuchert, as given by Osborn in his "Origin and Evolution of Life." ${ }_{33}$ The estimates of the duration of the geological periods vary greatly. The duration of the Proterozoic was as great, probably, as all post-Cambrian time, which has been estiniated as high as $100,000,000$ years. A study of radioactive substances gives estimates as high as $1,600,000,000$ years for the duration of the Archeozoic, although Walcott estimates that only $70,000,000$ years have elapsed since the beginning of sedimentation. While authors vary greatly in their estimates, they all agree that the duration of geological time has been very great, running into many millions of years. The

33 Osborn: "Origin and Evolution of Life," p.153. estimates given in the first column of the table are extremely conservative. I have followed Osborn in this column. In the second column a much greater estimate is given. The table will show the relative antiquity of various diseases, whatever values are assigned to the time estimates.

\section{FOSSIL PATHOLOGICAL LESIONS}

The following annotated list and illustrations of fossil lesions will indicate the extent of diseases among fossil vertebrates. The study of these lesions is by no means complete, and other pathological processes will doubtless be indicated as the study of them progresses.

I. Caries is very common among fossil rertebrates and has been described by Renault as occurring among Permian fishes, 20,000,000 years ago. A large marine reptile, from Belgium, one of the Cretaceous mosasaurs, according to Abel, shows in the left mandibular ramus extensive evidences of the ravages of this disease. In an early Tertiary species of the three-toed horse (Fig. 8), the mandible has been affected by caries and possibly also by actinomycosis, as well as some necrotic process which has resulted in the exposure of the roots of the teeth and the absorption of the alveolar margins, similar to the results of pyorrbea alveolaris. Caries has been noted also in the tooth of a mastodon, and in the early cave bears (Fig. 13) of Europe. The early races of men were singularly free from this disease as evidenced by the fossil remains.

2. Pyorrhea Alveolaris, or some similar pathologic process, is especially evident in the absorbed alveolar margins and in the loosened teeth of a three-toed horse (Fig. 8) from the Miocene of North America. It is also cxtensively indicated in the mandibles of the European cave bears (Fig. 13), and in a Cretaceous mosasaur from France.

3. Deforming Arthritides are fairly common among fossil vertebrates and indicate a variety of pathologic conditions. 
GEOLOGICAL EVIDENCES OF PALEOPATHOLOGY

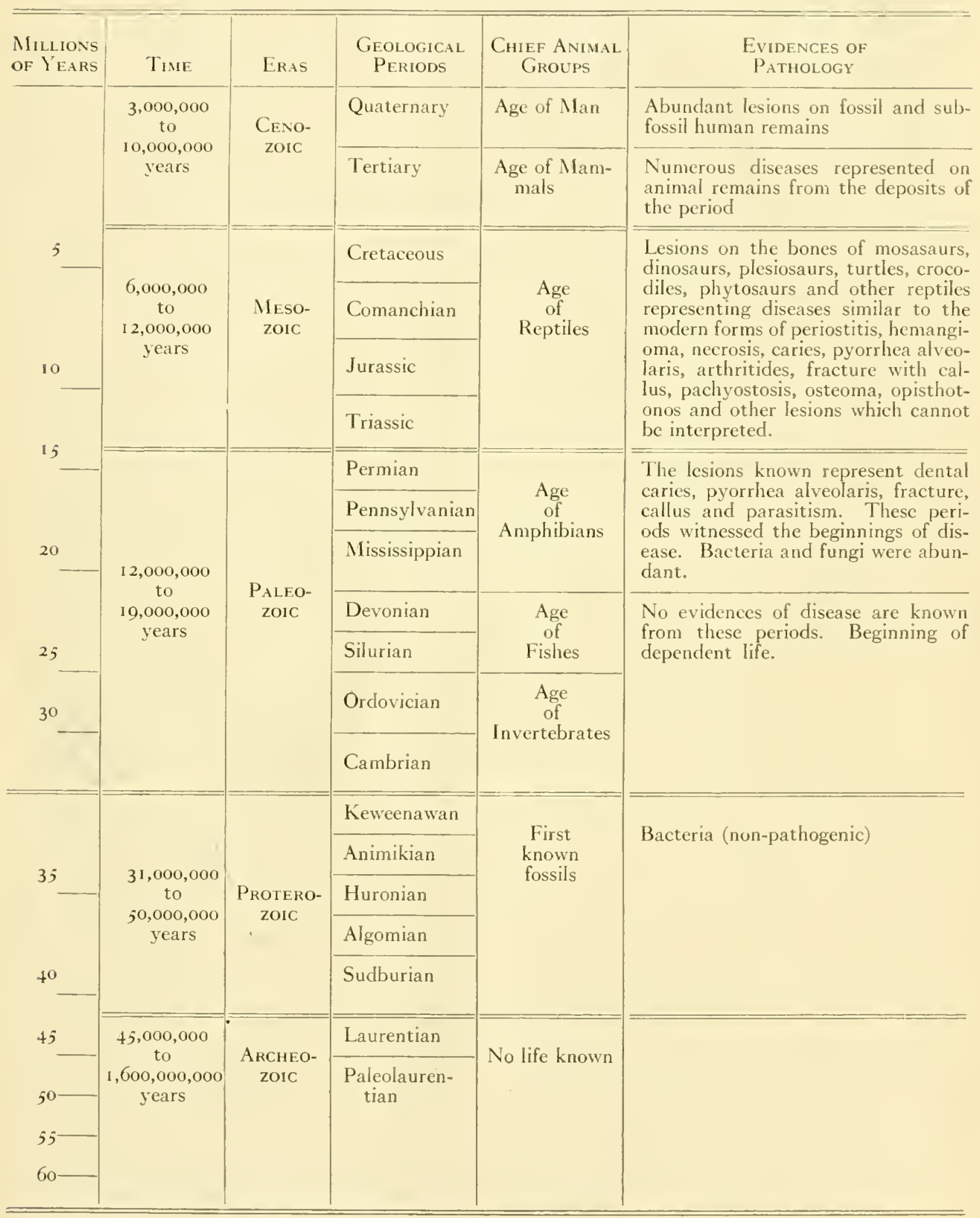


Arthritides are especially common in Pleistocene mammals. The most prominent case of a deformed joint is the case of two caudal vertebre (Fig. ${ }_{4}$ ) of a large dinosaur, the interarticular surfaces of which have been extensively deformed and surrounded by a huge exostosial growth. the middle of the tumor-like mass is 38.5 $\mathrm{cm}$. The lesion has involved a length of $12 \mathrm{~cm}$. Its surface generally is rather deeply pitted. There is an unusual ventral growth, which is shown in its normal condition in Fig. Is at "A." This bony process, "the chevron," which served to protect the cau-

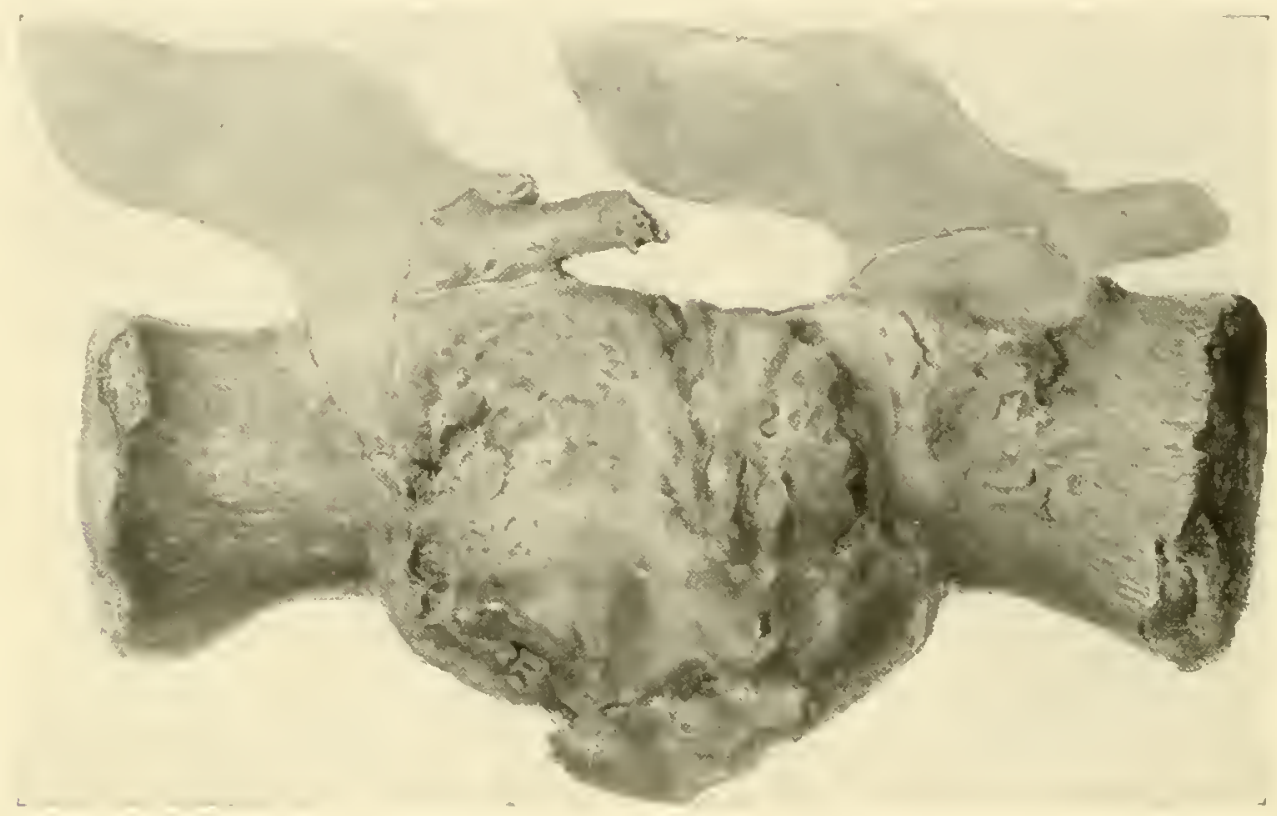

Fig. I4 Two caudal vertebræ of a sauropodous dinosaur, possibly Apatosaurus, exh biting a pathological lesion which may be interpreted as a hæmangioma, as a callus, as due to osteomyelitis or some unknown cause. This is one of the most inte esting evidences of disease among fossil animals so far studied. A detailed account of $t$ will be given later. Other lesions of a similar nature are fairly common among the dinosaurs of Nortls America and Europe. One-half natural size. The specimen is from the Como Beds, Comanchian, of Wyoming, and is the property of the Kansas University Museum of Natural History.

The mass resembles closely the tumorlike masses seen on oak trees. It entirely encircles the vertebræ and has involved fully half of the two bones. The dark line running vertically in the middle of Fig. I4 indicates the point where the normal union of the two vertebræ would occur, but all evidences of separate structures are obliterated, and the two vertebræ are fused into a single mass. The specimen has a length of $26.5 \mathrm{~cm}$. and a weight of $5.1 \mathrm{~kg}$. The circumference of the normal articular surface of one of the vertebræ measures $27 \mathrm{~cm}$., and the same measurement around dal vein and artery, is commonly present in the tail of these reptiles. The growth of the diseased portion is unequal and has inrolved more of the vertebre on one side than on the other; likewise, the growth has attained greater lateral dimensions on one side.

The enlargement is somewhat suggestive of the lesion of chronic osteomyelitis. It may be a callous growth, possibly due to a fracture of the caudal vertebræ; or it may be a bone tumor. The character of the lesion is naturally problematic, but it is interesting that pathological growths in the 
early geological periods so closely resemble the lesions of today. Section of the tumor mass shows the presence of numerous vascular spaces, so that in this respect it resembles a hæmangioma. Microscopic study of the periphery (Fig. 16) shows the presence of well-developed Haversian systems of osseous lamellie.

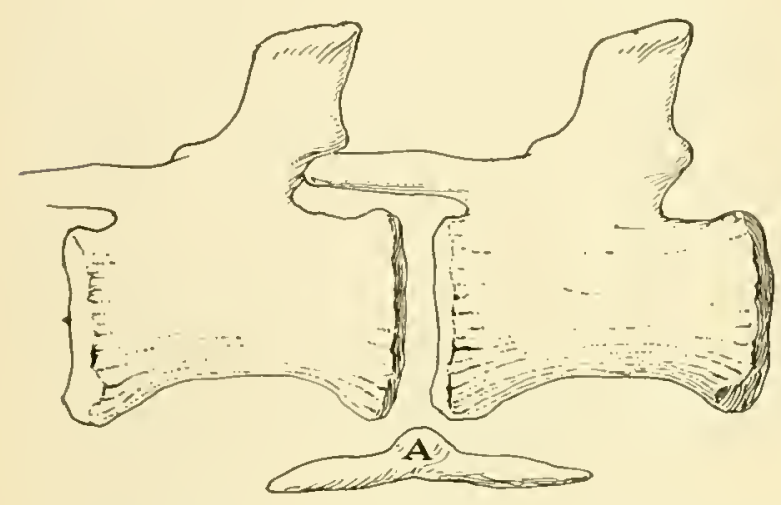

FiG. 15. Outline sketch showing normal appearance of the two vertebræ, based on Diplodocus and Apa osaurus. $\mathrm{A}=$ chevron. This process in the pathological specimen has been hoved far ventraiward and involved in the tumor-like mass.

The bones exhibiting these interesting indications of Mesozoic pathology are the caudal vertebrx of a huge land reptile, one of the sauropodous dinosaurs, possibly A patosaurus. The position of these bones in the body of the animal is indicated by the arrow in Fig. 17. The sauropodous dinosaurs were the most gigantic of all land vertebrates, although not nearly so large as some of the modern whales. The largest of these reptiles attained a length of nearly 70 feet and an estimated weight of 39 tons. The head was approximately the size of that of a modern draft horse and the contained brain was no larger than one's fist. The lumbar intumescence, however, was ten times the size of the cephalic portion of the nervous system, or at least the subdural space was. Whether the nervous material filled the entire cavity or not is unknown. The animals lived, possibly, in the swamps and low-lying rivers, feeding on the succulent

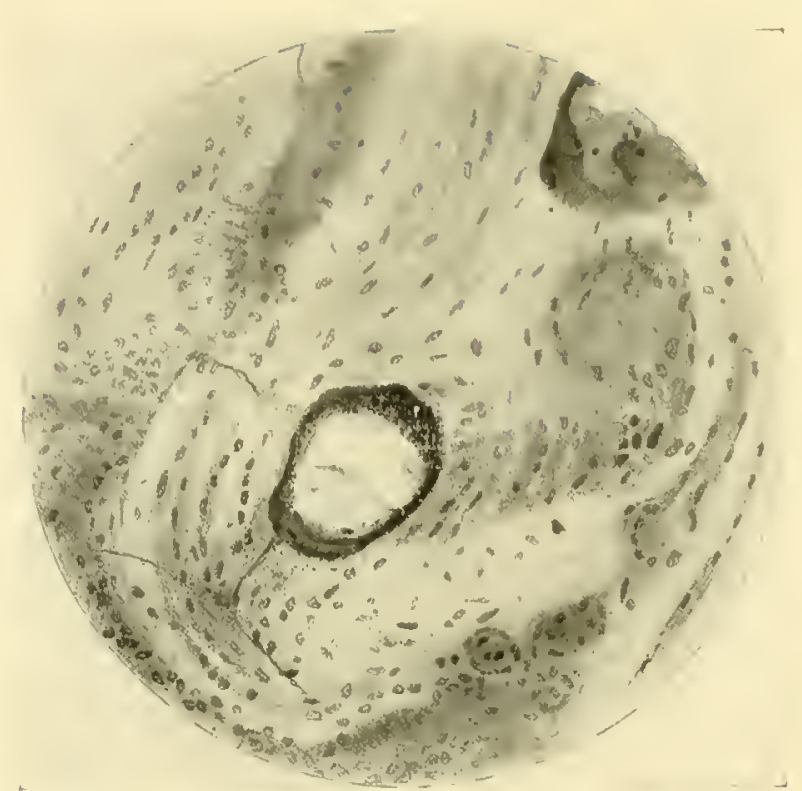

Fig 16. This figure will show the possibilities in the microscopic study of fossil bones. The drawing, 300 diameters, shows the osseous lacunx, with short canaliculi arranged around a large viscular opening, thus simulating an Haversian system. The lacunæ of dinosaur bones are much smaller than are the lacunx in other extinct forms. The clark areas are due to the staining of iron with which the bones are nfiltrated. The section was taken from the per phery of the specimen shown in Fig. 14.

vegetation, and are said to have been capable of attaining the ripe age of 1 , ooo years. Diseases are rarely seen on fossil dinosaur bones, in spite of the great abundance of their remains.

The tail in some of these large animals was very long and slender, and it may have been used in swimming, as a muskrat uses his today. The terminal caudals in some species were reduced to mere slender rods of bone, so that a fracture or an injury of

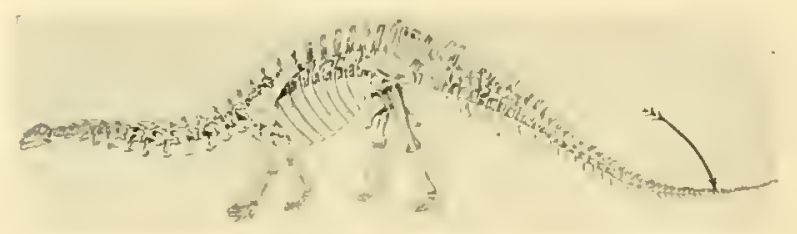

FIG. 17. Outline figure with skeleton, of Brontosaurus, showing at the arrow the location of the vertebra shown in Fig. 14. This animal attained a length of near y 70 feet, a leight of 15 feet and a weight of many tons. Based on a figu e by Matthew.) 
any kind in this region could easily occur. Aside from possible blows from the head, the dinosaur to which the above described vertebræ belonged was entirely defenseless. The tail, for example, might be seized by one of the carnivorous dinosaurs and vigorously chewed for some time before the owner of the tail was able to turn his huge body and knock the offender away.

Lesions of a similar nature, but not so well developed, are known to occur in the tail of Cetiosaurus Leedsi, an English dinosaur; and Hatcher has described the same lesions in the tail of Diplodocus. A fuller discussion of these lesions is reserved for another time.

The nature of the above-described lesion is such that it may have been due to bacterial activity, and suggests, at any rate, the presence of pathogenic bacteria in the early part of the Cretaceous period. Bacteria and primitive fungi have, indeed, been described from much older periods. The best account of their occurrence is contained in "Nlicroorganismes des combustibles fossiles," by B. Renault. ${ }^{34}$ Renault has described and figured many forms of bacteria and fungi in the fossilized feces (coprolites) of fishes, in fossil wood, and in coal. He has also discovered in the teeth of some ancient fishes what he regards as indications of the activity of organisms which have produced results similar to caries. He shows in one of his plates photomicrographs of fossil bone from the petrified feces in which the ravages of the bacteria, Micrococcus are evident in the canaliculi and the bone corpuscles, which appear in various stages of destruction.

Other deforming arthritides are represented by the arthritic condition sometimes spoken of as rheumatoid arthritis which has been noted by Virchow in the cave bears, by other observers in certain fossil human

${ }^{34}$ B. Renault: "Mieroorganismes des combustibles fossiles," Bull. Soc. de l'Industrie minérale SaintEtienne, Paris, 1899-1000, Tomes 13-14, with folio atlas of 20 plates of photomicrographs. skeletons, in the famous Lansing man of Kansas, ${ }^{35}$ and it is probably indicated in the Cretaceous mosasaurs, where a welldeveloped ostcoma accompanied the arthritic inflammation.

4. Osteomyelitis is probably indicated in the dinosaurian caudals figured herewith and in certain phalangeal elements of a grant wolf from the Pleistocene of California.

j. Exostoses due to trauma, indicated as callous growths around fractures of ribs and limb bones, or as outgrowths due to chronic irritation or infection, are fairly common among fossil vertebrates. Healed fractures (Fig. 7) are very common among mammals and are occasionally seen among fossil reptiles. Dinosaurs exhibiting broken ribs, vertebra, and horn cores attest the accidents or fights which caused these traumatic conditions, and has led Abel to infer that the males of these animals contested during the breeding season for the female. An exostosis which is especially clearly marked is evident on the inner or visceral surface of a dinosaur scapula, where it takes the form of a hook-like process, evidently due to chronic irritation. An exact duplicate of this lesion may be secn on a recent human femur. One of the most perfect exostoses is seen in a mosasaur from the Cretaceous of Kansas where there is a decided lump at the articular surface between the third and fourth dorsal vertebre, resulting in what is probably the only known fossil osteoma. Curious exostoses which are bilaterally symmetrical occur on the radii of an Oligocene dog, the skeleton of which is in the Carnegie Museum of Pittsburgh.

7. Osteosarcomata have not been positively identified among extinct animals, but the condition is suggested in several instances. Esper, in 1774 , described what he thought was an osteosarcoma in the femur of a cave bear, but Mayer, who studied

${ }^{35}$ Charles A. Parker: "Evidences of Rheumatoid Arthritis in the Lansing Man," Amer. Geol., 1904, vol. xxxiii. pp. 39-42. fig. I. 
the specimen later, suggrested that it might have been a fracture with callus and necrosis.

8. Fistule are evident in the lower jaw of an ancient and primitive whale from the Eoccne of Egypt, and an enlargement of the mandible of a three-toed horse from the Miocene of North America indicates the presence of a fistula, possibly due to actinomycosis, in its early stages. Dental fistulæ are occasionally seen among the known remains of fossil man, often resulting in the loss of teeth.

9. Rickets is indicated, according to Abel, among the apes which are found mummified in the old Egyptian graves.

Io. Necroses, due possibly to a variety of causes, and attributed by certain French writers to tuberculosis, are fairly common among fossil vertebrates. A marked necrosis of the ifium of a large dinosaur, accompanied by expansion and thickening of the bone, is evident in the mounted skeleton of Camptosaurus on exhibition at the National
Museum in Washington. A mosasaur bone from the Cretaceous of Kansas and certain crocodile limb bones from the Jurassic of England show lesions of a necrotic nature. The assignment of

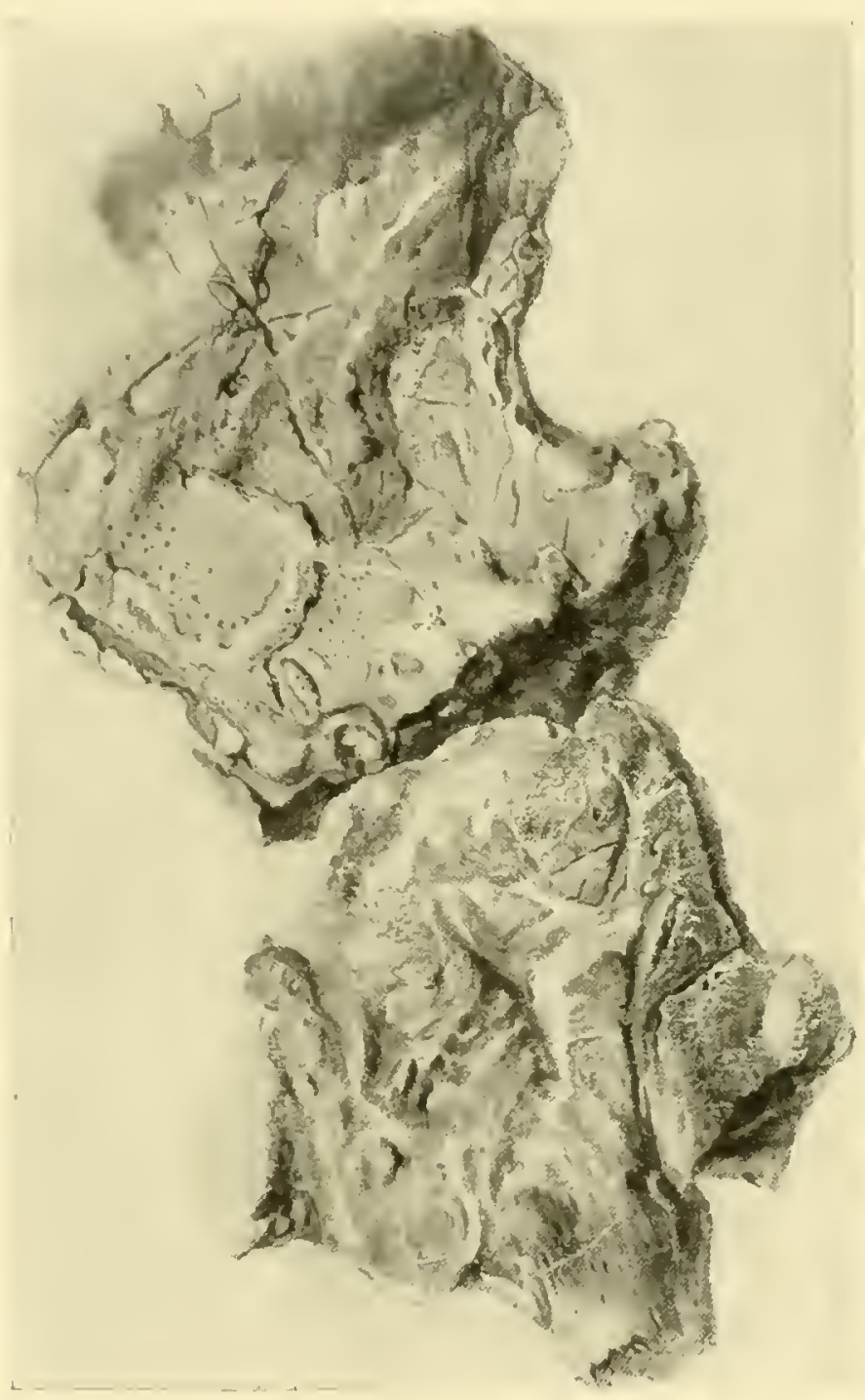

Fig. 18. The arm bones of a mosasaur from the Cretaceou of Kansas, showing lesions rescmbling osteoperiostitis. The la ge bone is the humerus, the other probably a radius. The rough surface of the bone indicates its pathology. Normal well-preserved specimens of these bones are quite smooth. The lesions have an arthritic nature also, though they are not confined to the articular surfaces. $x 1 / 2$.

The specimens are the property of the University of Kansas Museum of Natural History. any of the lesions to a definite cause is manifestly impossible, and while tuberculosis has been suggested as a possible cause, the diagnosis is so uncertain as to be nearly worthless. In the crocodile skeleton, above referred to, there is abundant evidence that the infection, the focus of which was in the pelvis, was carried by metastasis to the bones of the palate which were also involved, as well as other parts of the body.

II. HyperostoSIS Or PACHYOSTOSIS, which is similar to the enlargement of the bones in Gigantism, is indicated as thickened and enlarged portions of the skeleton. This condition has been detected in certain fossil Paleozoic fishes and Mesozoic reptiles, some of them of great geological antiquity. A genus of fossil whales, known as Pacbycantbus, has the neural, vertebral spines very greatly enlarged and swollen. 


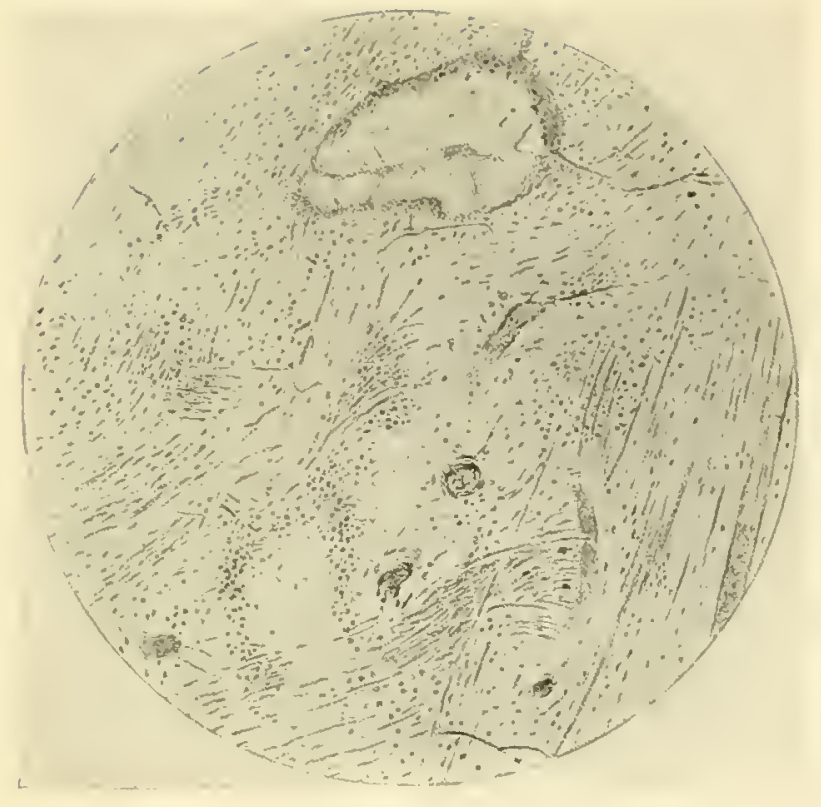

Fig. 19. Microscopic section of one of the lesions from the surface of the humerus, Fig. 1s, showing bundles of perforating fibers of Sharper, osseous lacunx, and vascular openings. The large clear space at the upper portion of the picture is a vascular opening filled with calcite crystals. 300 diameters.

A similiar condition is seen in the skeleton of a Triassic nothosaur. We are not justified in stating on these evidences the presence of pituitary disturbances in ancient animals, but further studies in this line may add very interesting data.

12. Osteoperiostitis or some similar disturbance is the result seen in the arm bones of a mosasaur from the Cretaceous of Kansas (Fig. 18). The articular surfaces are very greatly roughened and the surfaces of the bones are covered with smooth, somewhat flattened excrescences, possibly due to a subperiosteal irritation. The lesions have been observed in no other instances, so that no comparative statements can be made. Microscopic study of the peripheral lesions reveals many interesting histological details. One area shows typical osteoid tissue, similar in all essential respects to

${ }^{36}$ This subject has been discussed at length by the writer, in "Opisthotonos and Allied Phenomena among Fossil Vertebrates," American Naturalist, 1918. osteoid tissue developed in a human humerus in a case of ostcomyelitis. Other areas, such as the one figured (Fig. I9), show perforating fibers of Sharpey, as seen in the dark bundles, and the nature of the osseous lacunæ. The whole section is filled with vascular spaces. An especially large onc, filled with calcite crystals, is seen in the upper portion of the picture. There are no apparent Haversian systems or canals. II hether this is due to the pathology of the bone or whether it is an occurrence in normal bone of the mosasaurs will be determined later by microscopic study of the normal tissues.

13. Opisthotonos and the allied phenomena, pleurothotonos and emprosthotonos, are quite frequently seen among fossil vertebrates. It has been suggested elsewhere that these attitudes represent possible cercbrospinal infections or other neurotoxic conditions, and they must be considered in connection with the study of disease among fossil animals. ${ }^{36}$ The skeleton of the small dinosaur, Strutbiomimus altus (Fig. 20), described by Osborn, ${ }^{37}$ shows a very well-developed condition of opisthotonos, with the head thrown sharply back, the tail strongly flexed, and the toes contracted and appressed. The whole attitude strongly suggests a spastic distress, possibly brought on by some form of poisoning of the central nervous system, from infection or the deglutition of some poisonous substance.

14. Osteomalacia is evidently the cause of the hypertrophy of the bones of Limnocyon potens, an early carnivore from the Washakie Eocene of Wyoming, nearly 3,000,000 years old.

\section{MATERIALS AND METHODS}

The material described in the present paper has been loaned the writer for description by the Field Museum of Chicago,

${ }^{37}$ Osborn: Bull. Amer. Mus. Natl. Hist., 1917, vol. 35, p. 733 , pl. 28 . 
by the American Museum of Natural History of New York City, by Walker Museum of the University of Chicago, and by the University of Kansas Natural History Museum. made by the well-known petrographic methods so common in all geological laboratories. The diagnoses, where they are attempted, are made from comparisons of the

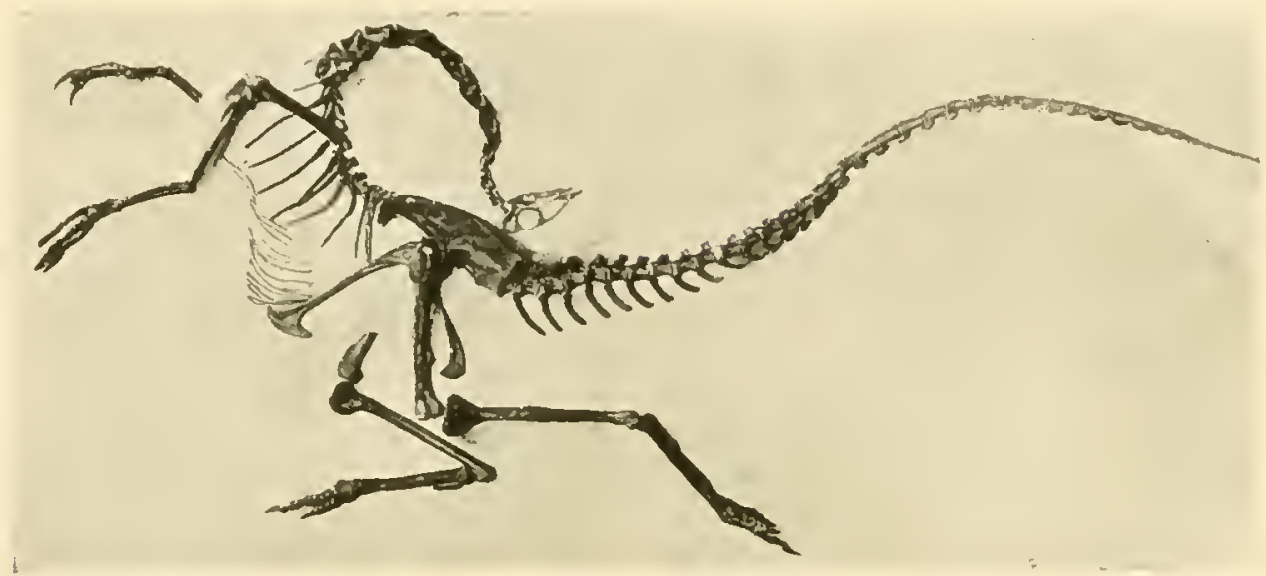

Fig. 20. The sheleton of Strutbiomimus altus, a stnall dinosaur from the Belly River series (Cretaceous), Red Deer River, Alberta, Canada, now regarded as of approximately the same age as the Judith River series. The unique feature of the skull is the total absence of teeth, with a size of skull one-third larger than the ostrich and a length of body of about fifteen feet. The position of the skeleton is decidedly that of the opistlotonos which may be regarded as an indication of disease. (After Osborn).

A beautiful specimen of an osteoma, the only one known so far, on the vertebra of a Kansas Cretaceous mosasaur, was given the writer by Dr. J. M. Armstrong of St. Paul. The writer expresses his obligations to the gentlemen connected with the above-mentioned institutions and to Dr. Armstrong.

The methods used are a combination of procedures in the various lines involved. Microscopic sections, which can be made thin enough for immersion lens study, are material with similar lesions in recent luman material; but strict diagnosis has not been attempted. We must have some name for the lesions, so the terms used must be regarded as suggestive rather than an accurate statement of conditions. The interpretation of the lesions in the fossil material is a matter of experience with fossil remains. The author feels that twelve years experience in the study of fossils should be sufficient to avoid most of the usual pitfalls. 







\section{Date Due}

Mait 191968 
